\title{
Tolerance to Hairy Chinch Bug Feeding in Kentucky Bluegrass ${ }^{1,2}$
}

\author{
P. B. BAKER, ${ }^{3}$ R. H. RATCLIFFE, ${ }^{4}$ AND A. L. STEINHAUER ${ }^{3}$ \\ ABSTRACT
}

Environ. Entomol. 10: 153-157 (1981)

Seventeen Kentucky bluegrass, Poa pratensis L., cultivars were evaluated for tolerance to feeding by adult hairy chinch bugs, Blissus leucopterus hirtus Montandon. Adults were confined on one month-old plants within a $10 \mathrm{~cm}$ diam $\times 20.3 \mathrm{~cm}$ high cylindrical plastic cage for 17-19 days. Cages were divided longitudinally so that $1 / 2$ of the plants in each pot were infested. Tolerance was evaluated as differences between infested and uninfested plants for height of regrowth, dry weight, yield of clippings, root length and weight, plant survival, tillering, and \% dry matter. Regrowth, yield of clippings, root length, and plant survival were significantly reduced and \% dry matter significantly increased in almost all cases by adult feeding. Dry weight, root weight, and tillering of plants were not significantly changed by feeding. Significant differences were found in tolerance among Kentucky bluegrass cultivars. Differences in cultivar regrowth, yield, and \% dry matter were the most useful criteria for measuring tolerance.

In the past, many of the major turfgrass insect pests, such as chinch bugs (Blissus spp.), sod webworms (Crambus spp.), billbugs (Sphenophorus spp.), and scarabaeid grubs, were controlled primarily by insecticides. During that time problems related to disease control or agronomic aspects of turfgrass production frequently received more attention than entomological problems because of the relative ease in controlling insects. More recently, however, insect problems in turfgrasses have become increasingly more evident as a result of the development of insecticide resistance by many insect pests and the unavailability of many insecticides. Also, with the frequent use of insecticides, entomologists became aware of other detrimental effects on the turfgrass ecosystem. Streu (1973) noted that the impact of multiple applications of insecticides over a number of seasons can be cumulative, resulting in pest resurgence, insecticide resistance, and other changes such as plant species succession and plant growth response. All of these problems emphasized the growing need to develop non-chemical control methods to reduce dependence on insecticides. Host plant resistance provides such an alternative for the suppression of insect damage, provided resistant germplasm can be identified and incorporated into agronomically acceptable cultivars.

The chinch bug complex, Blissus spp., consists of 15 species in the New World, with the most economically important species being the chinch bug, $B$. leucopterus leucopterus (Say) (formerly B. leucopterus); the hairy chinch bug, $B$. $l$. hirtus Montandon; and the southern chinch bug, $B$. insularis Barber (Leonard 1968). Members of this complex, particularly $B$. l. leucopterus, have been reported as pests of the Gramineae, specifically the small grains, since the 1780 's (Dahms et al. 1936, Snelling et al. 1937, Leonard 1966). The first report of chinch bug damage to a timothy pasture was from New York

\footnotetext{
'Hemiptera: Lygaeidae.

Scientific Article No. A.2876. Contribution No. 5929 of the Md. Agric. Exp. Stn. This research was sponsored under USDA, SEA, AR, Cooperative Agreemen No. 12-14-1001-617 between the Field Crops Laboratory and Univ. of MD. Pan of a dissertation submitted in partial fulfillment of the Ph.D. degree. Dept. of Entomology. University of Md. Received for publication April 7, 1980.

${ }^{3}$ Dept. of Entomology, University of Maryland, College Park, MD 20742. Senior author's present address: Dept. of Entomology, NY State Agric. Expt. Stn. Geneva, NY 14456.

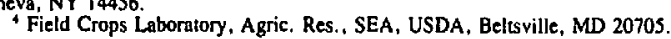

by Lintner (1883). Howard (1887) reported the first chinch bug damage on turfgrass in a Brooklyn, N.Y. lawn. However, it was not until recently that the hairy chinch bug was considered to be a serious pest of turfgrass due to the development of insecticide resistance (Streu and Cruz 1972). Selection for resistance to chinch bugs has been largely confined to corn and sorghum (Snelling et al. 1937, Dahms 1948). Field evaluation for resistance to $B$. leucopterus in forage grasses was reported by Hayes and Johnson (1925), but resistance in turfgrasses was not studied extensively until the early 1970 's when research on southern chinch bug resistance in St. Augustinegrass Stenotaphrum secundatum (Walt.) Kuntze was begun (Reinert and Dudeck 1974). Cooperative research in Texas and Florida resulted in the development and release of the chinch bug resistant St. Augustinegrass cultivar Floratam (Horn et al. 1973). There was a similar need to select for hairy chinch bug resistance in cool season turfgrasses.

The present study was designed for this purpose and was part of a larger research program to select for insect resistance in cool season forage and turfgrasses. The research reported here describes the results of investigations to determine plant responses to adult hairy chinch bug feeding, and methods developed to select for tolerance to feeding in Kentucky bluegrass, Poa pratensis L.

\section{Materials and Methods}

Four tests were conducted to evaluate Kentucky bluegrass cultivars for response to adult chinch bug feeding. The following general procedures were used in all tests. Grass cultivars were evaluated when ca. one month old. Each selection was seeded in $15.2 \mathrm{~cm}$ pots of sand in 4 groups (tufts) of seed per pot and cut to a $3.8 \mathrm{~cm}$ height after 3 wks. Sand was obtained from the field, screened, and the appropriate nutrients (N, P, K and micro-nutrients) and lime were added. Tufts were thinned to 5 plants each 7-10 days prior to infestation, and were cut to $3.8 \mathrm{~cm}$ the day of infestation. During infestation plants in each pot were confined within a clear plastic cylindrical cage $10 \mathrm{~cm}$ in diam and $20.3 \mathrm{~cm}$ high. Each cage was divided longitudinally by a flat piece of clear plastic glued between the halves of the cylinder. A 7.6 
cm hole was cut in each side and center section of the cage approximately $4.0 \mathrm{~cm}$ from the base and covered with 32 mesh/inch screen for ventilation. The screen on the sides of the cage was fastened so as to form a flap that could be opened to enable cutting of the grass without removal of the cage. Rubber bands and a piece of wood $(10.2 \times 2.0 \mathrm{~cm})$ were used to secure the flap. Adults were placed in one side of the cage; the other side served as an uninfested check. Cages were secured with white gravel on the inside and sand on the outside. Talcum powder was placed on the top $2 \mathrm{~cm}$ of surface of the infested side to prevent insects from escaping. Following an infestation period of 17-19 days, cages were removed, insects collected and counted. Height of regrowth, fresh and dry weight of clippings, \% dry matter, root development, plant survival, and tillering were also recorded. To enable root measurements, pots were submerged in a bucket of water until plants could be lifted free from the sand. Excess sand was washed free in a 2 nd bucket. The root length for each plant was then measured from the tips of the roots to the plant crown and measurements for the 5 plants in each tuft were averaged. Root weights were taken for each tuft of 5 plants after oven drying at $140^{\circ} \mathrm{C}$ for 3-5 days.

Insects used in these studies were 1st generation laboratory-reared adults, except in Test 3 , when field collected adults were used. All tests were conducted in a rearing room at $21-24^{\circ} \mathrm{C}, 50-80 \% \mathrm{RH}$ and a $14-\mathrm{h}$ photophase. Treatments were replicated 4 times in Tests 2 and 3 , and 5 times in Tests 1 and 4, using a randomized complete block design.

\section{Test 1}

The 5 cultivars, Adelphi, Baron, Fylking, Newport, and South Dakota Common (SDC) were chosen because of their diversified field responses to chinch bug feeding. An infestation rate of 2 adults/plant was used. Following removal of adults and recording of plant data, plants were allowed to regrow in the greenhouse without insects present (2nd cutting) for 19 days after which foliar and root measurements were taken.

\section{Test 2}

The same 5 cultivars were evaluated at infestation rates of 1 and 2 adults/plant. Second cutting data were not recorded. Root weight and \% organic matter were recorded after the 1st cutting.

\section{Test 3}

Fylking and SDC were evaluated at infestation rates of $1,1.5,2$, and 2.5 adults/plant. Second cutting data were taken as described for Test 1.

\section{Test 4}

Twelve cultivars (A-34, Adelphi, Bonnieblue, Campina, Delta, Geronimo, Kenblue, Newport, Parade, Park, Ram I, and Troy) with different agronomic characteristics were evaluated at an infestation rate of 1.5 adults/plant. Root measurements were taken after the 1st cutting

\section{Results and Discussion}

\section{Plant Response to Adult Feeding}

The effects of chinch bug feeding on plant responses is summarized in Table 1. Plant responses are shown
Table 1.-Effects of feeding by hairy chinch bug adults on plant responses for tests 1,2 , and 4 , respectively.

\begin{tabular}{|c|c|c|c|}
\hline \multirow[b]{2}{*}{ Plant responses } & \multicolumn{3}{|c|}{ No. of chinch bugs/plant ${ }^{1}$} \\
\hline & 2 & $1-2$ & 1.5 \\
\hline \multicolumn{4}{|l|}{ Regrowth (cm) } \\
\hline Infested & $4.4 \mathrm{a}$ & $7.5 \mathrm{a}$ & $2.0 \mathrm{a}$ \\
\hline Uninfestd & $22.2 \mathrm{~b}$ & $17.9 \mathrm{~b}$ & $13.7 \mathrm{~b}$ \\
\hline \multicolumn{4}{|c|}{ Dry Weight (mg) } \\
\hline Ínfested & $14.7 \mathrm{a}$ & $7.7 \mathrm{a}$ & $3.9 \mathrm{a}$ \\
\hline Uninfested & $26.1 b$ & $31.1 \mathrm{~b}$ & $27.3 b$ \\
\hline \multicolumn{4}{|c|}{ Root length $(\mathrm{cm})$} \\
\hline Infested & $9.3 \mathrm{a}$ & $10.6 \mathrm{a}$ & $3.9 \mathrm{a}$ \\
\hline Uninfested & $13.7 \mathrm{~b}$ & $13.1 \mathrm{~b}$ & $6.8 \mathrm{~b}$ \\
\hline \multicolumn{4}{|c|}{ Plant survival (\%) } \\
\hline Infested & $82.4 a$ & $96.0 \mathbf{a}$ & $41.0 \mathrm{a}$ \\
\hline Uninfested & $99.6 \mathrm{~b}$ & $99.3 \mathrm{a}$ & $96.2 b$ \\
\hline \multicolumn{4}{|l|}{$\%$ dry matter } \\
\hline Infested & $26.1 \mathrm{a}$ & $30.0 \mathrm{a}$ & $51.7 \mathrm{a}$ \\
\hline Uninfested & $14.7 \mathrm{~b}$ & $19.9 \mathrm{~b}$ & $20.2 \mathrm{~b}$ \\
\hline
\end{tabular}

1 Means for a given plant response within the same column not followed by same letter are significantly different at the $5 \%$ level as determined by t-test.

for 3 of the 4 tests and are an average for all cultivars in the respective tests. Data from Test 3 were not included because the infested value used in the analysis was based on an average of 4 infestation levels, while the value used in the other tests was based on only one or 2 infestation levels. In all cases, except plant survival in Test 2 , height of regrowth following infestation, yield of clippings, root length, and plant survival were significantly reduced by chinch bug infestation. Percent dry matter was significantly increased in all cases. Chinch bugs feed primarily in the phloem and xylem tissues of plants, resulting in stunted growth (Painter 1928) and thus could be a major contributor toward moisture depletion in the plant. This could account for the fact that infested plants contained a higher \% dry matter than the uninfested checks. The significant reduction in top and root growth resulting from adult feeding in these tests, helps to explain the severe injury sustained in the field from high chinch bug populations. An infestation rate of 1.5 adults/plant as used in Test 4 in the laboratory, would correspond to ca. 350 adults $/ 0.09 \mathrm{~m}^{2}$ in the field. Populations of this level and higher are common (Reinert and Kerr 1973). The results of these tests demonstrated the usefulness of the split-cage method employed, both to evaluate tolerance in the laboratory and to enable investigators to correlate plant responses in the laboratory with those in the field. In addition, the cage design enables one to cut grasses periodically while under infestation, to simulate conditions of insect infestation and cutting practices which occur in the field. By these methods it is possible to study the influence of the interaction of insect feeding and cutting practices on plant growth and survival.

\section{Tolerance Tests}

Painter (1951) defines tolerance as a basis of resistance in which the plant shows an ability to grow and reproduce itself or to repair injury to a marked degree while supporting a population ca. equal to that damaging a susceptible host. In this study tolerance was expressed as a \% difference from the uninfested check; the smaller the difference the more tolerant the cultivar. Differences 
were expressed as negative $(-)$ a reduction, or positive $(+)$, an increase from the uninfested checks.

Data from Tests 1 and 2 for Newport, Baron, and Adelphi are summarized in Table 2. Data for Fylking and SDC are not shown since their response was very similar to that of Adelphi. At 1st cutting there was no significant difference among Newport, Baron, or Adelphi for reduction in regrowth or yield except in Test 2 at an infestation rate of one adult/plant. In this instance reduction of regrowth for Baron was significantly less than that for Adelphi. The greatest difference in response of cultivars at 1 st cutting was in $\%$ dry matter increase over the uninfested control. Increase in \% dry matter of Adelphi was always greatest, but was significantly greater than that of Baron only in Test 2 at an infestation rate of 2 adults/plant. There was little difference in the expression of tolerance at 1 or 2 adults/ plant except that injury was more severe on all cultivars at the higher infestation rate, as would be expected.

Differences in cultivar tolerance were most clearly expressed at 2nd cutting in Test 1 (Table 2). This information was not available for Test 2 since roots were examined immediately after chinch bugs were removed. At 2 nd cutting Adelphi had significantly less regrowth and yield than both Newport and Baron and significantly less root growth (length) than Newport. There was very little difference in \% dry matter increase among cultivars at 2 nd cutting, since measurements were taken on plant material that was produced after insects were removed. The reduction in regrowth and yield at 2 nd cutting would indicate that even after insects are removed, plants are still under stress and recovery may be incomplete or prevented. Painter (1928) reported chinch bug injury is caused mainly by the withdrawal of fluids from the phloem and xylem tubes and stoppage of the conducting tissues by sheath materials, resulting in the starvation of roots for synthesized foods and moisture. Thus the effects of feeding injury may be prolonged for some time after insects are removed and differences in tolerance may be more clearly expressed on the basis of recovery after feeding has ceased rather than response during feeding. This measurement of tolerance is being explored further.

In Test 3, 1st cutting regrowth and yield were reduced at all infestation levels for both cultivars although differences among rates were significant only for SDC (Table 3). Reductions increased with an increase in infestation rates from 1 to 2 adults/plant and then leveled off. There was a significant \% reduction in regrowth on SDC between rates of 1 vs. 1.5 through 2.5 adults/plant and yield at 1 vs. 2.0 and 2.5. SDC showed significantly less \% dry matter differences at infestation rates of 1 and 1.5 adults/plant than at 2.5. At 2 nd cutting, SDC had significantly less \% reduction in regrowth at infestation rates of 1 and 1.5 vs. 2.5 adults/plant. Although SDC showed less reduction in regrowth than Fylking at the lowest infestation rate, both cultivars were very susceptible to adult chinch bug feeding injury. It appeared, however, that the greatest differences between uninfested and infested plants occurred between infestation rates of 1 and 2 adults/plant. Thus we decided that an infestation rate of 1.5 adults/plant would give a level of feeding pressure that would allow the greatest expression on differences among cultivars.

In Test 4 , based on $\%$ reduction in regrowth, Bonnieblue was significantly more tolerant than Kenblue, Ram I, A-34, Geronimo, Newport, Campina, and Adelphi (Table 4). Bonnieblue sustained significantly less yield loss than Campina. There was considerable variation in \% dry matter data and little significant differences among cultivars. However Troy showed the least effect of feeding on changes in \% dry matter and was significantly more tolerant than Campina. Bonnieblue and Delta showed significantly less \% reduction in root weight than Geronimo.

Results of the 4 tests demonstrated that certain criteria were more useful in determining tolerance than others. There were significant differences among cultivars in regrowth, yield, and \% dry matter in almost all tests, while little or no differences existed in tillering, root

Table 2.-Tolerance of Kentucky bluegrass cultivars to feeding by adult hairy chinch bugs expressed as \% differences between uninfested and infested plants of the same cultivar. Tests 1 and 2 .

\begin{tabular}{|c|c|c|c|c|c|c|c|c|}
\hline \multirow[b]{4}{*}{ Entry } & \multicolumn{8}{|c|}{$\%$ increase $(+)$ or decrease $(-)$ for plant response shown: } \\
\hline & \multirow{3}{*}{$\begin{array}{l}\text { No. } \\
\text { adults/plant }\end{array}$} & \multicolumn{2}{|c|}{ Regrowth } & \multicolumn{2}{|c|}{ Yield } & Root length & \multicolumn{2}{|c|}{$\%$ dry matter } \\
\hline & & \multicolumn{2}{|c|}{ Test no. } & \multicolumn{2}{|c|}{ Test no. } & Test no. & \multicolumn{2}{|c|}{ Test no. } \\
\hline & & 1 & 2 & 1 & 2 & 1 & 1 & 2 \\
\hline \multicolumn{9}{|c|}{ First Cutting } \\
\hline $\begin{array}{l}\text { Newport } \\
\text { Baron } \\
\text { Adelphi }\end{array}$ & 1 & - & $\begin{array}{l}-37.6 \mathrm{ab} \\
-35.3 \mathrm{~b} \\
-54.0 \mathrm{a}\end{array}$ & - & $\begin{array}{l}-62.4 \mathrm{a} \\
-52.2 \mathrm{a} \\
-71.9 \mathrm{a}\end{array}$ & - & - & $\begin{array}{r}+11.0 \mathrm{a} \\
+3.3 \mathrm{a} \\
+54.5 \mathrm{a}\end{array}$ \\
\hline Newport & 2 & $-71.0 a^{1}$ & $-66.6 \mathrm{a}$ & $-54.0 \mathrm{a}$ & $-82.9 \mathrm{a}$ & - & $+75.2 \mathrm{a}$ & $+54.1 \mathrm{ab}$ \\
\hline $\begin{array}{l}\text { Baron } \\
\text { Adelphi }\end{array}$ & & $\begin{array}{l}-80.9 a \\
-85.5 a\end{array}$ & $\begin{array}{l}-64.3 a \\
-66.6 a\end{array}$ & $\begin{array}{l}-54.0 \mathrm{a} \\
-77.0 \mathrm{a}\end{array}$ & $\begin{array}{l}-79.1 \mathrm{a} \\
-84.7 \mathrm{a}\end{array}$ & - & $\begin{array}{r}+67.0 \mathrm{a} \\
+113.7 \mathrm{a}\end{array}$ & $\begin{array}{r}+25.1 \mathrm{a} \\
+131.4 \mathrm{~b}\end{array}$ \\
\hline \multicolumn{9}{|c|}{ Second Cutting } \\
\hline $\begin{array}{l}\text { Newport } \\
\text { Baron } \\
\text { Adelphi }\end{array}$ & 2 & $\begin{array}{l}-4 \mathrm{l} .3 \mathrm{a} \\
-43.6 \mathrm{a} \\
-73.2 \mathrm{~b}\end{array}$ & - & $\begin{array}{l}-39.3 \mathrm{a} \\
-45.9 \mathrm{a} \\
-83.3 \mathrm{~b}\end{array}$ & - & $\begin{array}{l}-16.4 a \\
-27.3 \mathrm{ab} \\
-46.6 \mathrm{~b}\end{array}$ & $\begin{array}{r}+6.0 a \\
+4.1 \mathrm{a} \\
+10.1 \mathrm{a}\end{array}$ & - \\
\hline
\end{tabular}

' Means for a given variable followed by the same letter are not significantly different at the $5 \%$ level-DMR: comparisons apply only within same test and cutting. 
Table 3.-Tolerance of Kentucky bluegrass cultivars to feeding by adult hairy chinch bugs expressed as \% difference between uninfested and infested plants. ${ }^{1,2}$

\begin{tabular}{|c|c|c|c|c|c|c|}
\hline \multirow[b]{3}{*}{ Entry } & \multicolumn{6}{|c|}{$\%$ increase $(+)$ or decrease $(-)$ for plant response shown: } \\
\hline & \multirow{2}{*}{$\begin{array}{l}\text { No. } \\
\text { adults/plant }\end{array}$} & \multicolumn{3}{|c|}{ Ist cutting } & \multicolumn{2}{|c|}{ 2nd cutting } \\
\hline & & Regrowth & Yield & $\%$ dry matter & Regrowth & Yield \\
\hline $\begin{array}{l}\text { Fylking } \\
\text { Fylking } \\
\text { Fylking } \\
\text { Fylking }\end{array}$ & $\begin{array}{l}1.0 \\
1.5 \\
2.0 \\
2.5\end{array}$ & $\begin{array}{l}-65.3 \mathrm{a} \\
-65.2 \mathrm{a} \\
-79.9 \mathrm{a} \\
-82.9 \mathrm{a}\end{array}$ & $\begin{array}{l}-55.9 \mathrm{~b} \\
-67.5 \mathrm{ab} \\
-74.3 \mathrm{ab} \\
-80.7 \mathrm{ab}\end{array}$ & $\begin{array}{l}+74.7 \mathrm{ab} \\
+73.9 \mathrm{ab} \\
+115.1 \mathrm{~b} \\
+111.8 \mathrm{~b}\end{array}$ & $\begin{array}{l}-53.7 a b c \\
-67.4 a \\
-71.2 a \\
-82.9 a\end{array}$ & $\begin{array}{l}-81.8 a \\
-75.7 a \\
-78.9 a \\
-87.0 a\end{array}$ \\
\hline $\begin{array}{l}\text { S.D.C. } \\
\text { S.D.C. } \\
\text { S.D.C. } \\
\text { S.D.C. }\end{array}$ & $\begin{array}{l}1.0 \\
1.5 \\
2.0 \\
2.5\end{array}$ & $\begin{array}{l}-33.9 \mathrm{~b} \\
-63.1 \mathrm{a} \\
-83.3 \mathrm{a} \\
-82.0 \mathrm{a}\end{array}$ & $\begin{array}{l}-38.8 b \\
-67.7 a b \\
-89.5 a \\
-85.8 a\end{array}$ & $\begin{array}{l}+21.5 \mathrm{a} \\
+37.5 \mathrm{a} \\
+69.7 \mathrm{ab} \\
+119.4 \mathrm{~b}\end{array}$ & $\begin{array}{l}-22.3 c \\
-31.0 \mathrm{bc} \\
-61.7 \mathrm{ab} \\
-81.1 \mathrm{a}\end{array}$ & $\begin{array}{l}-68.7 a \\
-80.8 a \\
-93.9 a \\
-88.8 a\end{array}$ \\
\hline
\end{tabular}

Density level of 2 adultsiplant.

2 Means for a given variable followed by the same letter are not significantly different at the $5 \%$ level (DMR).

Table 4.-Tolerance of Kentucky bluegrass cultivars to feeding by adult hairy chinch bugs expressed as \% difference between uninfested and infested plants. ${ }^{1.2}$

\% increase $(+)$ or decrease $(-)$ for plant response shown:

\begin{tabular}{llllll} 
& & & & \multicolumn{2}{c}{ Root } \\
\cline { 5 - 6 } Entry & Regrowth & Yield & \% dry matter & Length & Weight \\
\hline Bonnieblue & $-72.6 \mathrm{c}$ & $-76.1 \mathrm{~b}$ & $+116.2 \mathrm{ab}$ & $-30.7 \mathrm{ab}$ & $-31.0 \mathrm{bc}$ \\
Delta & $-75.6 \mathrm{bc}$ & $-78.7 \mathrm{ab}$ & $+133.8 \mathrm{abc}$ & $-29.7 \mathrm{ab}$ & $-20.7 \mathrm{c}$ \\
Troy & $-81.1 \mathrm{abc}$ & $-77.8 \mathrm{ab}$ & $+45.5 \mathrm{a}$ & $-41.5 \mathrm{ab}$ & $-36.4 \mathrm{abc}$ \\
Park & $-83.1 \mathrm{abc}$ & $-83.2 \mathrm{ab}$ & $+141.7 \mathrm{abc}$ & $-33.9 \mathrm{ab}$ & $-38.9 \mathrm{abc}$ \\
Parade & $-85.2 \mathrm{abc}$ & $-87.0 \mathrm{ab}$ & $+171.7 \mathrm{abc}$ & $-50.9 \mathrm{ab}$ & $-46.2 \mathrm{abc}$ \\
Kenblue & $-87.5 \mathrm{ab}$ & $-88.2 \mathrm{ab}$ & $+122.6 \mathrm{ab}$ & $-45.4 \mathrm{ab}$ & $-46.7 \mathrm{abc}$ \\
Ram I & $-88.2 \mathrm{ab}$ & $-89.5 \mathrm{ab}$ & $+219.2 \mathrm{bc}$ & $-47.0 \mathrm{ab}$ & $-49.8 \mathrm{ab}$ \\
A-34 & $-88.4 \mathrm{ab}$ & $-86.6 \mathrm{ab}$ & $+168.8 \mathrm{abc}$ & $-18.7 \mathrm{~b}$ & $-32.5 \mathrm{abc}$ \\
Geronimo & $-88.6 \mathrm{ab}$ & $-87.4 \mathrm{ab}$ & $+128.0 \mathrm{ab}$ & $-56.3 \mathrm{a}$ & $-59.0 \mathrm{a}$ \\
Newport & $-88.7 \mathrm{ab}$ & $-82.3 \mathrm{ab}$ & $+143.0 \mathrm{abc}$ & $-42.7 \mathrm{ab}$ & $-45.2 \mathrm{abc}$ \\
Campina & $-90.2 \mathrm{a}$ & $-92.2 \mathrm{a}$ & $+170.5 \mathrm{abc}$ & $-52.4 \mathrm{ab}$ & $-49.1 \mathrm{ab}$ \\
Adelphi & $-91.6 \mathrm{a}$ & $-88.3 \mathrm{ab}$ & $+263.3 \mathrm{c}$ & $-43.8 \mathrm{ab}$ & $-37.2 \mathrm{abc}$ \\
\hline
\end{tabular}

Density level of 1.5 adults/plant.

* Means for a given variable followed by the same letter are not significantly different at the $5 \%$ level (DMR).

length, and plant survival. A comparison of the more useful criteria for determining tolerance (regrowth, yield, and \% dry matter) indicated, in general, that the responses of the cultivars from test to test were consistent. Thus, it appears that tolerance to chinch bug feeding might be consistently measured on the basis of reduction in regrowth and yield and possibly increase in \% dry matter.

The differences in tolerance expressed by some of the Kentucky bluegrass cultivars may be indicative of resistance present in other lines or species of turfgrass, and emphasizes the need for continuing research to identify germplasm with increased tolerance. A sufficient level of tolerance in grass cultivars could reduce injury sustained by plants from chinch bug feeding without subjecting insects to types or levels of resistance that could ultimately result in selection of resistant insect biotypes. However, the nature of factors contributing to the tolerance expressed by some Kentucky bluegrass cultivars needs to be studied further.

\section{Acknowledgment}

We gratefully acknowledge the statistical assistance of E. James Koch (Ret.), General Statistician, Biomet- rics, Beltsville Agric. Res. Center West, Beltsville, Maryland.

\section{REFERENCES CITED}

Dahms, R. G. 1948. Effect of different varieties and ages of sorghum on the biology of the chinch bug. J. Agric. Res. 76: $271-88$.

Dahms, R. G., R. O. Snelling, and F. A. Fenton. 1936. Effect of several varieties of sorghum and other host plants on the biology of the chinch bug. J. Econ. Entomol. 29: 1147-53.

Hayes, W. P., and C. O. Johnson. 1925. The reaction of certain grasses to chinch bug attack. J. Agric. Res. XXXI: 575-83.

Horn, G. C., A. E. Dudeck, and R. W. Toler. 1973. Floratam St. Augustinegrass. Univ. Fla. Agric. Exp. Stn. Circ. S-224: 13 pp.

Howard, L. O. 1887. The chinch bug (Blissus leucopterus) Say, Order Hemiptera; family Lygaeidae. Rpt. Entomologist USDA: 51-8.

Leonard, D. E. 1966. Biosystematics of the "leucopterus complex" of the genus Blissus. Conn. Agric. Exp. Stn. Bull. 677: 1-47.

Leonard, D. E. 1968. A revision of the genus Blissus (Lygaeidae) in eastern N. America. Ann. Entomol. Soc. Am. 61: $239-45$. 
Lintner, J. A. 1883. The chinch bug in New York. Science 2: 540 .

Painter, R. H. 1928. Notes on the injury to plant cells by chinch bug feeding. Ann. Entomol. Soc. Am. 21: 23241 .

Painter, R. H. 1951. Insect resistance in crop plants. Univ. London Press, London: 520 pp.

Reinert, J. A., and A. E. Dudeck. 1974. Southern chinch bug resistance in St. Augustine-grass. J. Econ. Entomol. 67: $275-7$.
Reinert, J. A., and S. H. Kerr. 1973. Bionomics and control of lawn chinch bugs. Bull. Entomol. Soc. Am. 19: 91-2.

Snelling, R. O., R. H. Painter, J. H. Parker, and W. M. Osborne. 1937. Resistance of sorghum to chinch bug. USDA Tech. Bull. 585: 56 pp.

Streu, H. T. 1973. Turfgrass ecosystem: Impact of pesticides Bull. Entomol. Soc. Am. 19: 89-90.

Streu, H. T., and C. Cruz. 1972. Control of the hairy chinch bug in turfgrass in the northeast with Dursban insecticide. Down to Earth 28: 1-4. 